\title{
Evaluating the Suitability of Application of Hydrological Models in a Mixed Land Use Watershed
}

\author{
Anil Acharya \\ Alabama Agricultural and Mechanical University, Normal, Alabama.
}

\begin{abstract}
This project compared the suitability of two hydrological models for the Flint River watershed (FRW). The Flint River flows into Wheeler Lake, which drains to the Tennessee River, a major source of water in northern Alabama. Two very widely used hydrological models, the Soil and Water Assessment Tool (SWAT) and the Storm Water Management Model (SWMM), were selected for this study. Both models were calibrated and validated for FRW. The calibration parameters were selected based on past research studies which used the same hydrologic models. The calibration parameters for SWMM and SWAT included basin, subbasin, soil, groundwater, channel and land use parameters. During calibration, both models were run at daily and monthly time steps, where simulated streamflows were compared with observed streamflows (years 2004-2013) and various statistical parameters were computed. While comparing simulated and observed monthly streamflows, SWAT showed better performance $\left(r=0.86-0.97, R^{2}=\right.$ $0.73-0.93$, bias $=12.2 \%$, RMSE $\left.=5.6 \mathrm{~m}^{3} / \mathrm{s}-8.9 \mathrm{~m}^{3} / \mathrm{s}\right)$ than SWMM $\left(r=0.70, R^{2}=0.50, \mathrm{RMSE}=2 \mathrm{~m}^{3} / \mathrm{s}-56 \mathrm{~m}^{3} / \mathrm{s}\right.$, bias $\left.=6.2 \%-8.4 \%\right) . \mathrm{How}-$ ever, both models showed better performance for monthly streamflows than for daily streamflows. The evaluation determined that SWAT provides a more suitable model than SWMM when applied to a mixed land use watershed like FRW.
\end{abstract}

\section{Background}

Hydrological models are common tools used to simulate rainfall and evaluate runoff at local to regional scales. Past studies have shown the development and application of various hydrological models for different regions and have evaluated hydrological impacts at a watershed scale. The types of models that were used depended on the watershed features (e.g. land use, soil, size of the watershed), climate (e.g. temperature, precipitation) and environmental factors (e.g. water quality, ecology), and their data availability. The use of hydrologic models depends on problem definition, specific objectives, availability of data and computing facilities, economic and social constraints, model classification, and performance evaluation (Dooge 1972; Xu 2002). Various studies have discussed the applicability of different hydrological models, their classification, use and limitations for a specific region (e.g. Devi et al. 2015; Dwarakish and Ganasri 2015; Elliott and Trowsdale 2007; Gosling et al. 2011; Haris et al. 2016; Jajarmizadeh et al. 2012; Plate 2009; Xu 1999; 2002; Zoppou 2001).

Hydrological modeling is performed mainly to simulate the components of the hydrological cycle and to incorporate their spatial and temporal features. However, the components and their importance vary depending on the overall goals and objectives of the study and the modeled study area. This study used two hydrological models and explored their suitability based on model effectiveness during calibration and validation at a watershed level. A fully distributed model needs more detailed data which may be difficult to get experimentally or from literature. A lumped model may require less detailed information but performs uniform simulations that may not fully represent sub-catchment physical processes. The study area selected also has to be comparatively large to use the lumped model. Two semi-distributed models were used for this study such that the modelling processes were based on sub-catchments and either lumped or distributed parameters could be used to simulate each subcatchment. The two models selected were developed principly for urban and agricultural watersheds. Both hydrological models are public-domain physically-based semi-distributed models for which required data were freely available online or from published research literature. The selected rainfall-runoff models contained both hydrological and hydraulic components coupled to a streamflow routing model, and simulations could be performed at the same time steps. Although model representation of all physical processes in the watershed is necessarily complex, some models include their own algorithms and have limitations due to the conditions of their initial development. Both models used in this study have been very widely used for hydrological, hydraulic and water quality impacts in different regions, at different scales, and for watersheds with varying land use patterns and watershed characteristics. This study concentrated on a mixed land use watershed and evaluated the models at a local scale.

Acharya, Anil. 2018. Evaluating the Suitability of Application of Hydrological Models in a Mixed Land Use Watershed.

Journal of Water Management Modeling 26: C456. doi: 10.14796/JWMM.C456.

(c) CHI 2018. www.chijournal.org ISSN 2292-6062. 
The approach taken in this study was to use two physically-based semi-distributed hydrological models with similar applications but differing initial model development assumptions. Model suitability was determined by how well the model performed for larger (sub)watersheds of mixed land use. Although the choice of models could be greater than the two used in this study, this paper can provide good insight for future studies that may use more than one hydrological model to perform impact assessment on larger watersheds with mixed land use and land cover. As this project continues, future evaluation of the models will include water quantity and quality. However, this paper evaluated model suitability based only on water quantity.

\section{Methodology}

\subsection{Characterization of the Study Areas}

This study was carried out on the Flint River watershed (FRW) which is a subwatershed of the Wheeler Lake watershed (WLW) in northern Alabama. The FRW $\left(1443 \mathrm{~km}^{2}, 564 \mathrm{mi}^{2}\right)$ and WLW $\left(7449 \mathrm{~km}^{2}, 2876 \mathrm{mi}^{2}\right)$ drain into the Tennessee River, a major source of water in the southeastern United States (ADEM 2008; TDEC 2016). This study used historical climate data (precipitation, minimum and maximum temperatures) available from four Alabama Mesonet stations (ALMNet; http://wx.aamu.edu/ ALMNet. php), located in the upper regions of FRW, which have operated since 2002. ALMNet stations are part of the National Resources Conservation Service (NRCS) Soil Climate Analysis Network (SCAN) stations. The stream gauge station that was used in this study is operated by the U.S. Geological Survey (USGS) and is in Brownsboro, Alabama (USGS 03575100), as shown in Figure 1. FRW is of mixed land use predominantly consisting of forest, agri-cropland, agri-pasture, and urban land uses. Based on the National Land Cover Dataset (NLCD) during the years 2006 and 2011, higher conversion was observed for some land uses (urban, agri-pasture and agri-cropland). An increase of urban land use in the range $2 \%-8 \%$ was observed due to reductions in agri-pasture and agri-cropland in the upper and lower subbasins inside FRW (Majors and Acharya 2015).

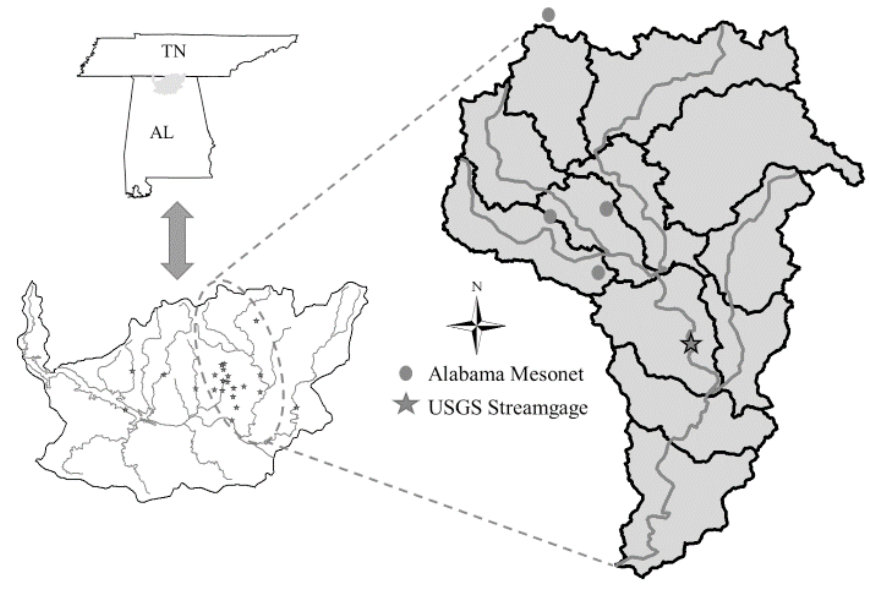

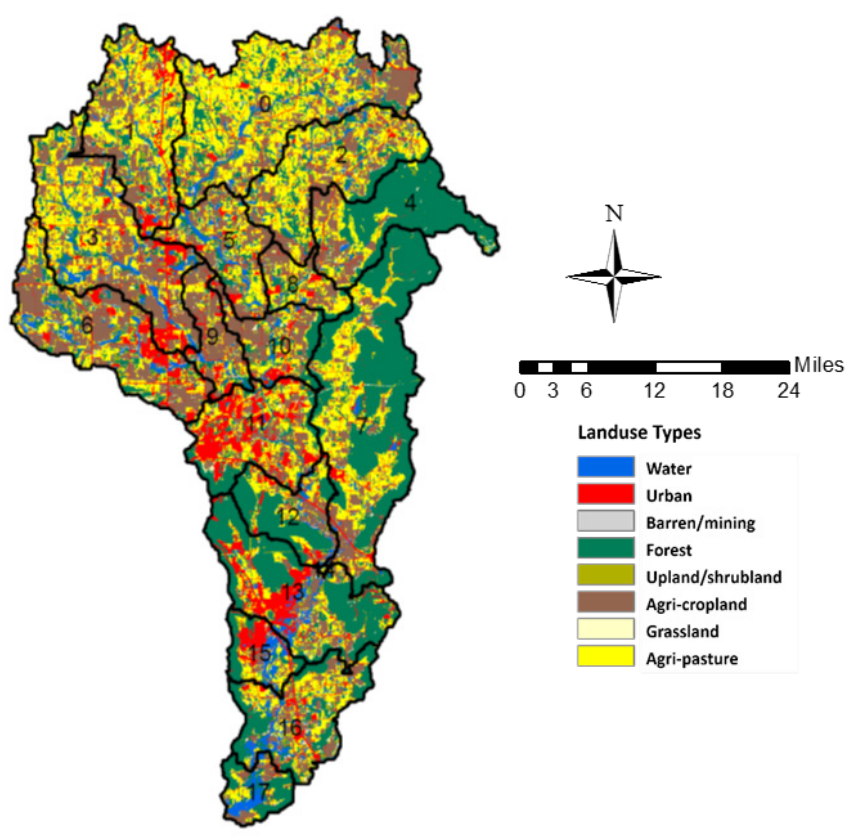

Figure 1 (a) Location of the Wheeler Lake watershed and Flint River watershed (FRW), Flint River tributaries, Alabama Mesonet stations (filled circles) and stream gauge station (filled star) inside FRW (not to scale; adapted from Acharya 2017); (b) land use classification of FRW based on National Land Cover data for 2011.

\subsection{Hydrological Models}

Two hydrological models, the Soil and Water Assessment Tool (SWAT) and the Storm Water Management Model (SWMM), were selected for this study. Both models were calibrated and validated for FRW. Both models used the water balance principle at catchment and subcatchment scales. Snowmelt (snowpack) was not considered in either model for this study on the assumption that there is no significant snow contribution to FRW. As discussed earlier, both models have been widely used in urban and nonurban applications in many regions.

SWAT is a physically-based and distributed-parameter watershed-scale model. It was developed to quantify the impacts of climate and land management practices on hydrology, water quality and sediment for watersheds with various watershed properties such as size, soil, land use or management practices.

SWAT was initially developed to manage water availability and non-point source pollution, and develop TMDLs (total maximum daily loads) for agricultural watersheds. SWAT can also simulate upland and channel processes and quantify pollutant loading under various land uses and land management scenarios. Although urban drainage systems were not fully represented and treated in SWAT, the model's application has been extended to and successfully implemented for various regions, including urban watersheds, thereby making SWAT a competitive water quality model for urban watersheds (Kuhn 2014). Some related 
applications of SWAT include predicting the impacts of land use change, climate change and management practices on water quantity (Acharya 2015; Lin et al. 2009; Santhi et al. 2006; Van Liew et al. 2007) and quality (Bracmort et al. 2006; Brzozowski et al. 2011; Pisinaras et al. 2010; Zhang et al. 2003).

In SWAT, each subcatchment consists of a number of hydrologic response units (HRUs), where each HRU represents an area having the same land use, soil cover, and land management conditions. Each HRU generates runoff which is routed through a reach or the main channel associated with each subcatchment and enters the stream reaches and channel network to give total runoff. Channel geometry and channel roughness, soil properties, and bank storage are considered important for runoff generation in the reaches and channels. The lateral subsurface flow in each soil layer is modeled based on a kinematic storage model embedded in SWAT. The lateral flow calculation is based on various parameters such as hydraulic conductivity, hill slope, soil porosity, soil water content, field capacity and recharge (Neitsch et al. 2009). The major losses in SWAT are calculated as infiltration, interception in terms of canopy storage, evapotranspiration, and abstraction or transmission losses for ephemeral streams. The canopy storage represents the amount of water intercepted by the vegetation canopy during precipitation which is later lost to the atmosphere through evaporation. The canopy storage is different depending on the leaf area index for each land cover in the basin. The ArcGIS-ArcView extension and the graphical user input interface for SWAT, ArcSWAT (V2012.10.14) (http://swat.tamu.edu/ software/arcswat/), were used in this study and the model was run for daily and monthly time steps. Neitsch et al. (2002) give a detailed description of the major parameters (input and output) used in the SWAT model and the sequence of processes during modeling. The major input parameters include watershed boundary, climate and weather, elevation and soil parameters and the model outputs are runoff, evapotranspiration (ET), sediments, nutrients and heavy metals. The ArcSWAT model also has an autocalibration feature which is performed by the external application SWAT Calibration and Uncertainty Procedures (SWAT-CUP). SWAT-CUP is public domain software which performs model calibration, uncertainty analysis, and sensitivity analysis (EAWAG 2016).

The SWMM model is a dynamic rainfall-runoff model which is principly used for simulating single and continuous rainfall events in urban areas to plan and design drainage facilities for stormwater runoff and sanitary sewers. The SWMM version 5.0 (SWMM 5.0) used in this study is freely available to download. It is maintained by the United States Environmental Protection Agency (USEPA), and commonly known as EPASWMM. EPASWMM does not incorporate autocalibration features so requires manual changes in parameters during the simulation process. An iterative calibration process (trial and error) was followed by adjustment of model parameters within the specified range (see Table 1 below) in order to obtain a better fit between observed and simulated hydrographs. Some relevant applications of SWMM include watershed management and low impact development (Altman et al. 1993; Morris and Asunskis 2002; Rivard 2010; Zhang and Guo 2015), the impacts of climate and land use change on stream hydrology and water quality (Kim et al. 2011; Tiveron et al. 2018; Tsihrintzis and Hamid 1998; Wu et al. 2013), and other hydrological impact assessments (Bhaduri et al. 2001; Jang et al. 2007; Judi et al. 2009). Simulations can be carried out in sub-hourly, hourly, sub-daily or daily time steps in SWMM. SWMM includes four major components (Atmospheric-Rain Gauge objects, Land Surface-Subcatchment objects, Groundwater-Aquifer objects and Transport-Node and Link objects) through which it incorporates various input parameters (e.g. climate, channels or conduits, junctions, elevations, watershed, soil, routing, storage, treatment, pollution and land use) and output parameters (e.g. peak runoff and pollutant loading). Of the four components, only three components (atmospheric, land surface, transport) were used in this study.

In SWMM, each subcatchment generates runoff based on precipitation which is routed through a system of pipes and channels (the conveyance system) located downstream to give total runoff. Channel geometry along with pervious and impervious areas, channel roughness values, and soil properties are considered important to runoff generation in the channels. Groundwater flow is modeled using aquifer objects which receive infiltration from each subcatchment and contribute to base flow (Rossman 2010). Groundwater flow is sometimes considered an external inflow in SWMM since aquifer objects are created separately and linked to subcatchments as required. As mentioned earlier, groundwater compartment (flow) was not considered or calibrated for this study due to lack of the detailed additional information (porosity, wilting point, field capacity, conductivity and conductivity slope, tension slope, evaporation fraction and depth, groundwater loss rate, moisture, and bottom and water table elevations) required for the aquifer. The major loss components in SWMM are infiltration, evaporation and initial abstraction (IA) where IA includes interception and depression storage based on the unit hydrograph and IA parameters. This study did not use IA parameters and made no calculation of IA.

\subsection{Calibration}

FRW was divided into a number of subwatersheds and the hydrological models were calibrated at daily and monthly time steps using various calibration parameters. SWMM can simulate both single and continuous events, and runs in daily or more frequent time steps. SWAT is used for continuous events but is not event based. Although hourly outputs are possible in SWAT, simulations can be carried out only at a minimum of daily or less frequent time steps. Thus model simulations were carried out at the minimum of daily time steps and results for both models were compared. The BASINS tool (Better Assessment Science Integrating Point and Nonpoint Sources) was used to set up the modeling framework for the SWMM model (USEPA 2015) and the SWAT model was defined inside ArcSWAT. The modeling framework included subbasin delineation, the locations of weather stations, subbasin characteristics, major reaches and watershed outlets. 
Both models were calibrated by changing various parameters within their ranges and performing sensitivity analysis. Selection of suitable parameters for use during calibration which are directly related to the physical processes in the watershed represented inside the model is a difficult task. Estimation of all selected parameter values based on field measurements or experiments is challenging and difficult (Jacomino and Fields 1997). Most of the calibration parameters selected in this study and the ranges of their values were selected based on literature that used similar hydrological models to this study.

The calibration parameters for SWMM and major literature references are summarized in Table 1. The major calibrated parameters included basin (width, percent impervious, percent slope imported from BASINS), subbasin (Nimpervious, Npervious, Simpervious, Spervious), conduit roughness $(N)$, and infiltration characteristics related to the Green-Ampt method (suction head, $\psi$; saturated hydraulic conductivity, $K$; maximum soil moisture deficit, IMDmax) and the Horton equation (Min and Max infiltration, Decay, Dry Time).

Table 1 Selected calibration parameters for SWMM model.

\begin{tabular}{|c|c|c|}
\hline Parameter & Range & References \\
\hline Percent Impervious & $\pm 10 \%$ & \\
\hline Width & $\pm 30 \%$ & \\
\hline Slope & $\pm 30 \%$ & \\
\hline Nimpervious (impervious & $0.01-0.015$ & \\
\hline $\begin{array}{l}\text { area roughness) } \\
\text { Npervious (pervious area } \\
\text { roughness) }\end{array}$ & $0.02-0.4$ & $\begin{array}{l}\text { SWMM Manual (Rossman 2010) } \\
\text { and other references discussed } \\
\text { in text. }\end{array}$ \\
\hline Manning's N & $\begin{array}{c}0.01-0.1 \text { (Conduits); } \\
0.011-0.015 \text { (Overland Flow); } \\
0.02-0.14 \text { (Open Channels) }\end{array}$ & \\
\hline S-Impervious & $(0.3-2.3) \mathrm{mm},(0.012-0.091$ in. $)$ & Huber and Dickinson 1988 \\
\hline (impervious depression & $(0.05-0.15)$ in. & USDCM 2016 (Table 6-6) \\
\hline$\frac{\text { Storage, IDS) }}{\text { S-pervious }}$ & $\frac{(0.05-0.1) \text { in. }}{(2.5-5.1) \mathrm{mm},(0.098-0.201) \text { in. }}$ & $\begin{array}{l}\text { SWMM Manual } \\
\text { Huber and Dickinson } 1988\end{array}$ \\
\hline (pervious depression & $(0.2-0.6)$ in. & USDCM 2016 (Table 6-6) \\
\hline$\frac{\text { storage, PDS) }}{\text { Min. Infiltration }}$ & $\frac{(0.1-0.3) \text { in. }}{(0.01-0.5) \text { in. } / \mathrm{h}}$ & SWMM Manual \\
\hline Max. Infiltration & $(1-5)$ in./h & SWMM Manual \\
\hline Decay & $2-7$ & \\
\hline Dry Time & $(2-14) d$ & \\
\hline$\overline{\psi(\text { suction head) for soil }}$ & (1.93-12.6) in. & SWMM Manual (Table A.2) \\
\hline$\frac{\text { type: clay to sand }}{K \text { (conductivity) }}$ & $\frac{(9.7-253) \mathrm{mm},(0.388-9.96) \mathrm{in} .}{0.01-4.74 \mathrm{in} . / \mathrm{h}}$ & $\begin{array}{l}\text { Chow et al. } 1988 \\
\text { SWMM Manual (Table A.2) }\end{array}$ \\
\hline IMDmax (initial soil & $0.37-0.50$ (in fraction) & Chow et al. 1988 \\
\hline moisture deficit) & $0.398-0.50$ & SWMM Manual (Table A.2) \\
\hline
\end{tabular}

The calibration parameters for SWAT along with major references are summarized in Table 2. The major calibrated parameters include basin (SURLAG, ESCO, EPCO), subbasin (CANMX), soil (SOL_AWC(1) \%, SOL_K(1) \%, SOL_BD(1)), groundwater and its recharge (ALPHA_BF, GWQMIN, GW_DELAY, REVAPMN, RCHRG_DP, GW_REVAP), channel routing ( $\mathrm{CH} \_\mathrm{N} 2, \mathrm{CH}$ _K2, ALPHA_BNK), and land use or management (CN2 \%). During calibration, simulated streamflows were compared with observed historical streamflows at USGS 03575100 . Both models were calibrated and validated during the periods 2004-2008, and 2009-2013 respectively. The performance of each model in simulating historical daily and monthly streamflows for FRW were evaluated using various statistics such as the coefficient of correlation $(r)$, the coefficient of determination $\left(R^{2}\right)$, bias percentage, the mean square error (MSE), root mean square error (RMSE) and Nash-Sutcliffe efficiency (NSCE).

Table 2 Selected calibration parameters for SWAT model.

\begin{tabular}{|c|c|c|c|}
\hline Parameters & Type & Range & References \\
\hline$\overline{A L P H A \_B F}$ &.$g w$ & $0.1-1.00$ & $\begin{array}{l}\text { Van Liew et al. 2007; Santhi et al. } \\
\text { 2006; SWAT User's Manual (Neitsch } \\
\text { et al. 2002) }\end{array}$ \\
\hline GW_DELAY & & $0-500$ & \\
\hline GWQMIN & & $0-5000$ & \\
\hline REVAPMN & & $0-500$ & \\
\hline RCHRG_DP & & $0.0-1.0$ & \\
\hline GW_REVAP & & $0.02-0.4$ & \\
\hline CH_N2 & rte & $0.02-0.15$ & Chow 1959; SWAT User's Manual \\
\hline CH_K2 & & $0.01-250$ & \\
\hline ALPHA_BNK & & $0.0-1.0$ & \\
\hline$\overline{\text { SURLAG }}$ &.$b s n$ & $0.05-20$ & SWAT User's Manual \\
\hline $\mathrm{ESCO}$ & & $0.01-1.0$ & \\
\hline EPCO & & $0.01-1.0$ & \\
\hline $\mathrm{CN} 2(\%)$ & .mgt & $-0.2-0.2$ & Santhi et al. 2006; Van Liew et al. \\
\hline CANMX & .hru & $\begin{array}{c}(-20 \%-20 \%) \\
0.01-5.0\end{array}$ & $\begin{array}{l}2007 \\
\text { SWAT User's Manual }\end{array}$ \\
\hline SOL_AWC(1) (\%) & sol & $-0.5-0.5$ & \\
\hline SOL_K(1) (\%) & & $\begin{array}{c}(-50 \%-50 \%) \\
-0.25-0.25\end{array}$ & \\
\hline SOL_BD(1) & & $\begin{array}{c}(-25 \%-25 \%) \\
1.1-1.9\end{array}$ & \\
\hline
\end{tabular}

\section{Results}

\subsection{SWMM Model Calibration}

FRW was divided into subbasins. The total area of subbasins located upstream and draining into USGS 03575100 was considered during model calibration and validation. SWMM was calibrated by varying major parameters (as summarized in Table 1) within their ranges and performing sensitivity analysis. Of the three infiltration models (Horton, Green-Ampt and Curve Number) available within the SWMM model, the Horton equation and the Green-Ampt model were used during model calibration. SWMM can use parameters as lumped or distributed for each infiltration model. Both options were used for each infiltration model and simulations were carried out to compare the results given by both approaches. As discussed earlier, calibration parameters were obtained based on watershed characteristics (available from watershed boundary maps) and relevant literature. Calibration was performed for both infiltration methods and the model was run twice for each method. Model parameters were lumped for one run and distributed for the other run to observe which option gave the better SWMM model performance. 
Table 3 summarizes the final values of the calibrated parameters based on daily time steps. The table also summarizes calibration statistics to simulate observed daily and monthly streamflows. Comparison of simulated and observed streamflows for daily and monthly time steps for both methods resulted in similar correlation coefficients (daily $r=0.35$ and monthly $r=0.70$ ). The simulated daily streamflows did not correlate well with observed streamflows. RMSE was higher for lumped calibration compared to distributed calibration. In comparing both infiltration methods, RMSE was higher for the Horton method except during monthly time steps. RMSE varied from $74 \mathrm{~m}^{3} / \mathrm{s}$ to $178 \mathrm{~m}^{3} / \mathrm{s}$ for daily time steps, and from $2 \mathrm{~m}^{3} / \mathrm{s}$ to $56 \mathrm{~m}^{3} / \mathrm{s}$ for monthly time steps. The bias was $6 \%$ for daily time steps and $6.2 \%-8.4 \%$ for monthly time steps during the study period. The lower NSCE index (0.08-0.16 for daily time steps, $0.13-0.23$ for monthly time steps) indicates model streamflow simulations were unacceptable in uncertainty, and unsatisfactory for conducting further analysis with the same model setup.

Table 3 SWMM model calibration results.

\begin{tabular}{|c|c|c|c|c|}
\hline \multirow{2}{*}{$\frac{\text { Parameters }}{\text { Infiltration Method }}$} & \multicolumn{4}{|c|}{ Calibrated Values } \\
\hline & Horton & Horton & Green-Ampt & Green-Ampt \\
\hline Calibration Type & Lumped & Distributed & Lumped & Distributed \\
\hline Time Steps & Daily & Daily & Daily & Daily \\
\hline Percent Impervious & $\pm 10 \%$ & $\pm 10 \%$ & $\pm 10 \%$ & $\pm 10 \%$ \\
\hline Width & $\pm 30 \%$ & $\pm 30 \%$ & $\pm 30 \%$ & $\pm 30 \%$ \\
\hline Slope & $\pm 30 \%$ & $\pm 30 \%$ & $\pm 30 \%$ & $\pm 30 \%$ \\
\hline Nimpervious & 0.012 & $0.010-0.014$ & 0.0136 & $0.010-0.015$ \\
\hline Npervious & 0.399 & $0.055-0.399$ & 0.399 & $0.020-0.398$ \\
\hline $\begin{array}{l}\text { Manning's } N \text { (open } \\
\text { channel) }\end{array}$ & 0.064 & $0.03-0.12$ & 0.093 & $0.020-0.389$ \\
\hline S-Impervious & 0.025 & $0.017-0.087$ & 0.023 & $0.020-0.148$ \\
\hline S-pervious & 0.138 & $0.108-0.181$ & 0.489 & $0.098-0.576$ \\
\hline Min Infiltration & 0.031 & $0.012-0.348$ & & \\
\hline Max Infiltration & 4.999 & $1.301-4.987$ & & \\
\hline Decay & 2.031 & $2.001-6.783$ & & \\
\hline Dry Time & 2.014 & $2.962-13.960$ & & \\
\hline$\psi$ & & & 12.549 & $5.441-11.178$ \\
\hline K & & & 0.5148 & $0.698-4.666$ \\
\hline \multirow[t]{2}{*}{ IMDmax } & & & 0.407 & $0.381-0.422$ \\
\hline & \multicolumn{4}{|c|}{ Calibration Statistics (Daily) } \\
\hline$r$ & 0.35 & 0.35 & 0.33 & 0.35 \\
\hline $\operatorname{RMSE}\left(\mathrm{m}^{3} / \mathrm{s}\right)$ & 178 & 121 & 113 & 74 \\
\hline \multirow[t]{2}{*}{ NSCE (\%) } & 0.08 & 0.10 & 0.14 & 0.16 \\
\hline & \multicolumn{4}{|c|}{ Calibration Statistics (Monthly) } \\
\hline$r$ & 0.70 & 0.70 & 0.70 & 0.69 \\
\hline $\operatorname{RMSE}\left(\mathrm{m}^{3} / \mathrm{s}\right)$ & 56 & 2.0 & 17.9 & 12.7 \\
\hline NSCE (\%) & 0.13 & 0.23 & 0.20 & 0.22 \\
\hline
\end{tabular}

Figure 2 shows the comparison of simulated (using the Green-Ampt infiltration method) and observed monthly streamflows during the period 2004-2013. Simulated streamflows represent base flow well but underestimate some higher peaks (e.g. 2011-2012) and overestimate lower peaks (e.g. 2005-2006,
2009-2011). As shown in Table 3, change in calibration parameters based on different models (lumped or distributed) and methods (Horton or Green-Ampt) did not improve the results significantly. However, using a range of parameters based on a distributed model minimized RMSE for both methods $\left(56 \mathrm{~m}^{3} / \mathrm{s}\right.$ to $2 \mathrm{~m}^{3} / \mathrm{s}$ for Horton, $17.9 \mathrm{~m}^{3} / \mathrm{s}$ to $12.7 \mathrm{~m}^{3} / \mathrm{s}$ for Green-Ampt).

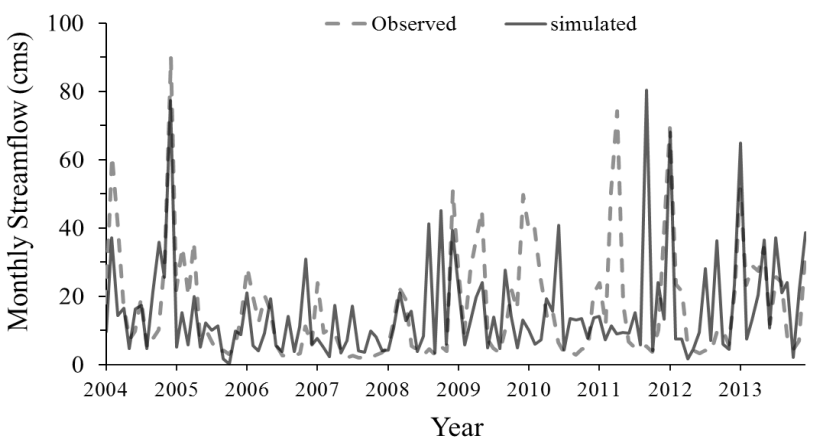

Figure 2 Modeled vs observed monthly streamflow $\left(\mathrm{m}^{3} / \mathrm{s}\right)$ during the period 2004-2013 using the Green-Ampt infiltration method in SWMM.

\subsection{SWAT Model Calibration}

The SWAT model was calibrated and validated using daily (2004-2009) and monthly (2010-2013) streamflow data. Table 4 summarizes the calibrated parameters, their final values and calculated statistics based on simulated and observed daily and monthly streamflows. The SWAT model was also run for two cases (case 1 and case 2), which is helpful in evaluating model effectiveness in simulating observed streamflows for different conditions. Case 1 results were calculated with land use $<5 \%$ lumped, soil $<10 \%$ lumped, and slope $<20 \%$ lumped. Lumped here represents that the percentages of land use, soil and slope that were less than the assigned threshold percentage were not considered during model simulation. Case 2 was simulated by reducing the lumped percentage to a minimum value to check if any significant changes in results occurred compared to the results from case 1 . Case 2 results were calculated based on 0 land use lumped, soil $<5 \%$ lumped and slope $<10 \%$ lumped.

Comparison of simulated and observed daily streamflows showed a good representation of base flows and peak flows during the study period (2004-2013). As shown in Figure 3 (for case 2), both simulated and observed daily streamflows during the calibration period (2004-2008) followed similar patterns and magnitudes except for some extreme streamflows (e.g. 2004). A lower magnitude for extreme streamflows during the starting period could be due to a model limitation in simulating extreme peaks during the warming up period (usually taken to be $2 \mathrm{y}-3 \mathrm{y}$ from startup). The calculated statistics for both cases (case 1 and case 2) and for daily and monthly streamflows are summarized in Table 4. For both cases, simulated daily streamflows resulted in good $r(0.60-0.80)$ and $R^{2}(0.37-0.63)$, higher NSCE index (0.380.63 for daily, $0.72-0.89$ for monthly), lower bias (12.1\%-13.8\%), 
and lower RMSE $\left(22 \mathrm{~m}^{3} / \mathrm{s}-31 \mathrm{~m}^{3} / \mathrm{s}\right)$ compared to calibration statistics (see Table 3 above) for SWMM. The higher NSCE index indicates that model streamflow simulation was acceptable and adequate to perform additional analysis with the same model setup.

Table 4 SWAT model calibration results.

\begin{tabular}{lcclll}
\hline \multicolumn{1}{c}{ Parameters } & \multicolumn{2}{c}{ Calibrated Values } & \multicolumn{2}{c}{$\begin{array}{c}\text { Calibration/Validation Results } \\
\text { Case 1 }\end{array}$} \\
& Case 1 & Case 2 & \multicolumn{2}{c}{ Case 2 } \\
\hline ALPHA_BF & 1.000 & 0.469 & \multicolumn{2}{c}{ Daily } \\
GW_DELAY & 0.010 & 0.091 & $r=0.78 / 0.63$ & $r=0.80 / 0.60$ \\
GWQMIN & 1000 & 10.350 & $R^{2}=0.62 / 0.40$ & $R^{2}=0.63 / 0.37$ \\
REVAPMN & 98.775 & 312.160 & Bias $=13.8 \%$ & Bias $=12.1 \%$ \\
RCHRG_DP & 0.327 & 0.054 & MSE $=577 / 991 \mathrm{~m}^{3} / \mathrm{s}$ & MSE $=505 / 1009 \mathrm{~m}^{3} / \mathrm{s}$ \\
GW_REVAP & 0.033 & 0.400 & RMSE $=24 / 31 \mathrm{~m}^{3} / \mathrm{s}$ & RMSE $=22 / 31 \mathrm{~m}^{3} / \mathrm{s}$ \\
CH_N2 & 0.024 & 0.150 & NSCE $=0.55 / 0.40$ & NSCE $=0.63 / 0.38$ \\
CH_K2 & 249.590 & 136.020 & & \\
ALPHA_BNK & 0.975 & 0.993 & & \\
SURLAG & 20.000 & 11.646 & & Monthly \\
ESCO & 0.215 & 0.233 & $r=0.95 / 0.86$ & $r=0.97 / 0.86$ \\
EPCO & 1.000 & 0.637 & $R^{2}=0.90 / 0.73$ & $R^{2}=0.93 / 0.73$ \\
CN2 (\%) & 0.180 & 0.196 & Bias $=13.9 \%$ & Bias $=12.2 \%$ \\
CANMX & 0.118 & 5.000 & MSE $=53 / 86 \mathrm{~m}^{3} / \mathrm{s}$ & MSE $=31 / 79 \mathrm{~m}^{3} / \mathrm{s}$ \\
SOL_AWC(1) (\%) & -0.399 & 0.500 & RMSE $=7.2 / 9.2 \mathrm{~m}^{3} / \mathrm{s}$ & RMSE $=5.6 / 8.9 \mathrm{~m}^{3} / \mathrm{s}$ \\
SOL_K(1) (\%) & -0.217 & 0.171 & NSCE $=0.79 / 0.72$ & NSCE $=0.89 / 0.74$ \\
SOL_BD(1) & 1.100 & 1.100 & & \\
\hline
\end{tabular}

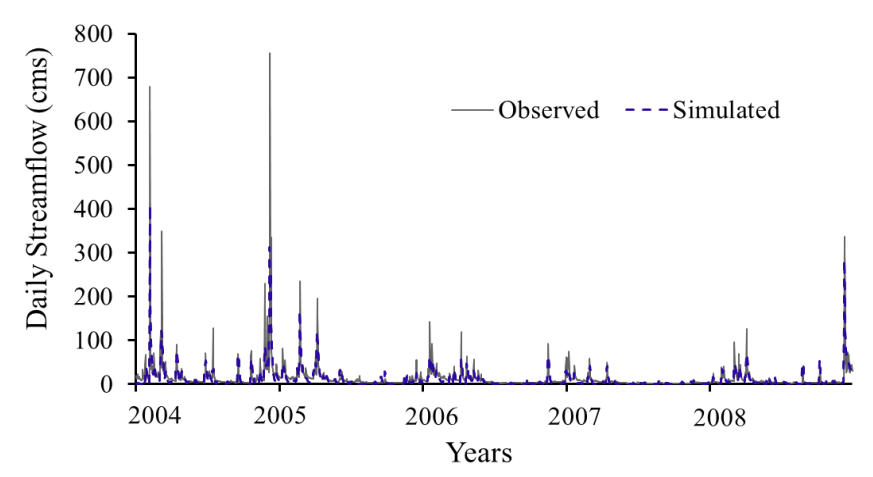

Figure 3 Comparison of simulated and observed daily streamflows during 2004-2013 (case 2).

Figure 4 shows the comparison of simulated and observed monthly streamflows during the period 2004-2013 for cases 1 and 2. Simulated monthly streamflows followed similar patterns for both cases with some differences in magnitude only; the simulated streamflows were comparatively higher for case 2 than case 1. For both cases, simulated monthly streamflows showed a very good representation of observed monthly streamflows and resulted in better statistics compared to daily streamflows. For case 1, base flows and most of the lower peaks were well represented except for some underestimation of higher peaks (e.g. 2004-2005, 2009-2011). For case 2, both base flows and peak flows were well represented during 2004-2013 (except
2011). As summarized in Table 4, simulated monthly streamflows for both cases resulted in higher $r(0.86-0.97)$ and $R^{2}(0.73-0.93)$, lower bias (12.2\%-13.9\%), and lower RMSE (5.6 m³ $\left./ \mathrm{s}-9.2 \mathrm{~m}^{3} / \mathrm{s}\right)$. A comparatively better performance for case 2 was due to different model run conditions as discussed earlier (land use not lumped, soil $<5 \%$ lumped and slope $<10 \%$ lumped). Changing basin characteristics, soil and land use conditions directly affected various components of the hydrological cycle (e.g. soil moisture storage, infiltration, evaporation, transpiration and base flows) and thus resulted in higher or lower streamflows.
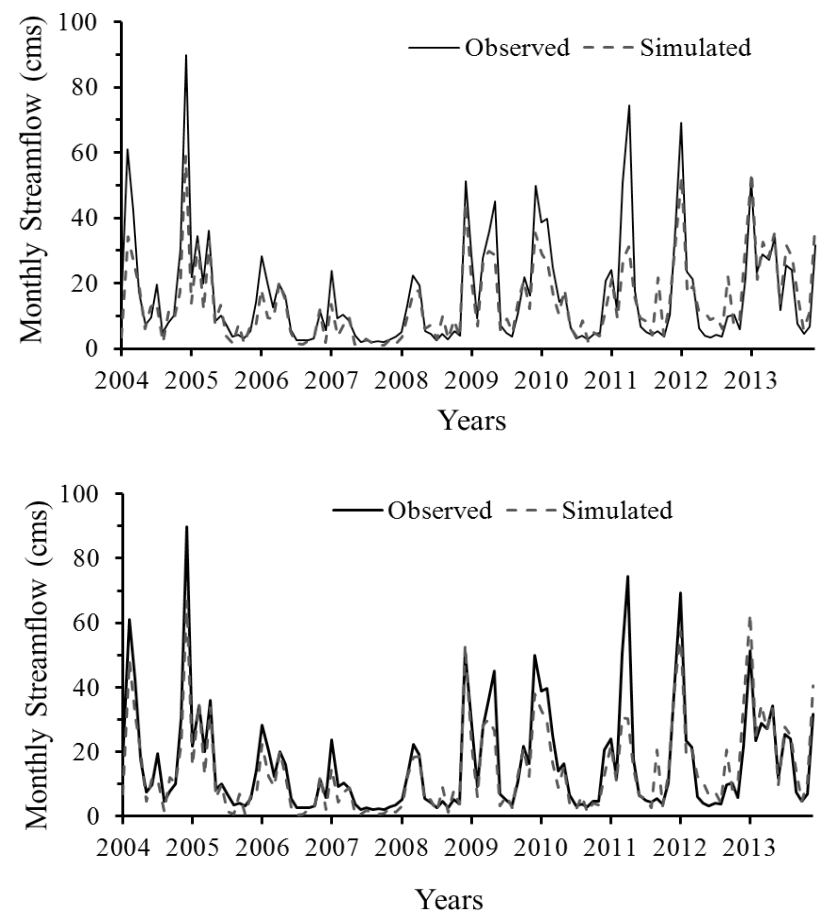

Figure 4 Comparison of simulated and observed monthly streamflows during 2004 to 2013; (a) case 1: land use $<5 \%$ lumped, soil $<10 \%$ lumped, and slope $<20 \%$ lumped; (b) case 2: 0 land use lumped, soil $<5 \%$ lumped, and slope $<10 \%$ lumped.

\section{Conclusions}

This study evaluated the suitability of the application of two widely used hydrological models (SWMM and SWAT) in a mixed land use watershed. Both models have been used in various studies in the past and were found to be effective in various regions and conditions. Both models were initially developed for specific purposes and have limitations. Thus this study is very relevant for particular study areas where the application of models varies based on their effectiveness. The results from this study depended on the initial model development assumptions related to the model application. SWAT was found to be more effective for areas of FRW that consisted of mixed land use with predominantly forest and agricultural land uses. Results based on visual streamflow patterns and statistical calculations showed SWAT to 
be more suitable than SWMM for FRW. In a parallel ongoing study (Acharya 2017) a calibrated SWAT model was used to evaluate the impacts of climate change on water quantity for FRW. However, one should always consider the limitations of the study before its application.

As discussed earlier, hundreds of references could be found which showed much better results for SWMM compared to this study when it was used for an urban environment (which is what SWMM was initially developed for) and smaller drainage areas. Again, additional studies have also showed better simulation statistics when SWMM was used for rural, semiurban or mixed land use watersheds where basin area was very small, smaller than (larger numbers of studies) or of similar size to (countable number of studies) this study area. The results given by SWMM in this study were comparatively poor and unacceptable for additional analysis without modification. However, in comparison to results from this study, other studies with better statistics were found to have used different modeling setups (considered as aquifer orgroundwater components), to have a dominant land cover of mixed land use, to use different or updated model versions (SWMM 5.1 or PCSWMM), to have smaller subcatchment areas draining to the outlet, to include more weather stations and more observed streamflow locations (gauges) inside the watershed during calibration, to use different calibration techniques (e.g. fewer parameters for the trial and error method or auto calibration if available), to have different simulation time steps (subdaily or hourly based on data availability), to give single storm or rainfall event based simulation, and to use different routing techniques (kinematic or dynamic wave). Examples of these difference can be found in Beling et al. 2011, Chen et al. 2016, Chung et al. 2011, El-Sharif 1998, Jang et al. 2007, Jun et al. 2010, Perrelli and Irvine 2013, Smith et al. 2005 and Tillinghast et al. 2011.

Some of the major difference just listed might have contributed to the weaker performance of SWMM in runoff prediction although it was difficult to exactly infer the cause of the poor results based solely on this case study. Unlike major studies that have demonstrated the application of SWMM in a small storm hydrology, for this study the model was calibrated for a larger watershed ( $60 \%$ of FRW area, $\sim 860 \mathrm{~km} 2$, drained to the calibrated point) and used larger subcatchments (varying from $18 \mathrm{~km}^{2}$ to $168 \mathrm{~km}^{2}$ ), and drained at a single outlet downstream rather than at an outlet for each subcatchment. Therefore, the accuracy of rainfall runoff and simulated runoff that was routed to each sub-catchment was reduced for larger and elongated subcatchments in this study (Camorani et al. 2005). Additional flow gauge stations at subcatchment outlets and the discretization of basins into smaller subbasins would improve verification and help to predict streamflow more accurately for larger basins. This study calculated infiltration loss with no consideration of groundwater flow. The study catchment is predominantly pervious (agricultural and forested land uses), so increased infiltration and baseflow contributed to total streamflow during significant rainfall events. However, the underestimation of some peak flows and total streamflow volume could be due to lack of a groundwater parameter and the use of daily time steps in the simulation. The simulation results from this study should be further tested and verified by using an updated model with increased parameterization, including infiltration or recharge to the aquifer in order to incorporate groundwater flow, to more completely predict total streamflow. Although the use of reliable climate data (for this study, mainly rainfall distribution data) is always recommended for the better overall performance of both models, the use of dynamic wave routing (to account for backwater effects, if any) and model simulation at smaller time steps (to capture peak and extreme flows) is suggested to improve SWMM model results.

On the other hand, better simulation results for the SWAT model could be obtained through various factors, as discussed earlier, such as applying SWAT to predominantly agricultural and forested land uses (which is what SWAT was initially developed for), the use of an up-to-date SWAT version that includes autocalibration (better sensitivity and uncertainty analysis), the consideration of groundwater flow that contributes additional total runoff volume, continuous simulation, and the calculation of water balance and runoff volumes while representing watershed and physical processes through HRUs.

The results and conclusions obtained from this study are limited to FRW and watersheds with similar characteristics. Application of a model is not restricted to a single watershed and its characteristics, but model suitability for any region can be evaluated in a manner similar to that used in this study. The types of models and modeling techniques used in this study can be applied to watersheds of various scales. However, comparison with more hydrologic models, and longer time series data (e.g. climate, soil and land use) records to perform extended periods of calibration will provide more insights to the selection of suitable hydrological models and additional analysis of the watershed. The use of experimental or observed parameter values to represent various physical processes within the model would reduce the number of calibration parameters, improve calibration results, and provide a better analysis of model outcomes.

\section{Acknowledgments}

This research is supported by the USDA-NIFA Capacity Grant Award \# 2013-38821-21130 and is a part of the Geospatial Research and Education Center project at Alabama A\&M University.

\section{References}

Acharya, A. 2015. "Modeled Hydrologic Response under Climate Change Impacts over the Bankhead National Forest in Northern Alabama." European Scientific Journal November 2015 (special edition):140-54. http://eujournal.org/index.php/esj/article/view/6526/6251

Acharya, A. 2017. "Quantification of Modeled Streamflows under Climate Change over the Flint River Watershed in Northern Alabama." Journal of Hydrologic Engineering 22 (9). https://doi.org/10.1061/(ASCE)HE.1943-5584.0001549. 
ADEM (Alabama Department of Environmental Management). 2008. Total Maximum Daily Load (TMDL) for Flint River: Pathogens (Fecal Coliform). Montgomery, AL: Alabama Department of Environmental Management, Water Quality Branch. Assessment Unit ID\# AL06030002-0401-102.

Altman, G. D., R. G. Montgomery, T. I. King and C. W. Patterson. 1993. "GIS and SWMM Applications in Developing the Lake Houston Watershed Management Program." In Proceedings of the National Annual Conference on Hydraulic Engineering, ASCE, San Francisco, California, July 25-30, 1993, 2239-44. New York: American Society Of Civil Engineers.

Beling, F.A., J. I. B. Garcia, E. M. C. D. Paiva, G. A. P. Bastos and J. B. D. Paiva. 2011. "Analysis of the SWMM Model Parameters for Runoff Evaluation in Periurban Basins from Southern Brazil." In 12ICUD, 12th International Conference on Urban Drainage, 11-16. London: International Water Association.

Bhaduri, B., M. Minner, S. Tatalovich and J. Harbor. 2001. “LongTerm Hydrological Impact of Urbanization: A Tale of Two Models." Journal of Water Resources Planning and Management 127 (1): 13-9.

Bracmort, K. S., M. Arabi, J. R. Frankenberger, B. A. Engel and J. G. Arnold. 2006. “Modeling Long-Term Water Quality Impact of Structural BMPs." Transactions of the ASABE 49 (2): 367-74.

Brzozowski, J., Z. Miatkowski, D. Sliwinski, K. Smarzynska and M. Smietanka. 2011. "Application of SWAT Model to Small Agricultural Catchment in Poland." Journal of Water and Land Management 15:157-66.

Camorani G, A. Castellarin and A. Brath. 2006. “Effects of Land-Use Changes on the Hydrologic Response of Reclamation Systems." Physics and Chemistry of the Earth 30:561-74.

Chen, C. F., L. Y. Tsai, C. H. Fan and J. Y. Lin. 2016. “Using Exceedance Probability to Determine Total Maximum Daily Loads for Reservoir Water Quality Management." Water 8 (11): 541. https://doi.org/10.3390/w8110541

Chow, V. T. 1959. Open-Channel Hydraulics. New York: McGraw-Hill.

Chow, V. T., D. R. Maidment and L. W. Mays. 1988. Applied Hydrology. New York: McGraw-Hill.

Chung, E. S., W. P. Hong, K. Lee and S. Burian. 2011. “Integrated Use of a Continuous Simulation Model and Multi-Attribute Decision-Making for Ranking Urban Watershed Management Alternatives." Water Resources Management 25 (2): 641-59.

Devi, G. K., B. P. Ganasri and G. S. Dwarakish. 2015. “A Review on Hydrological Models." Aquatic Procedia 2015:1001-7. https://doi.org/10.1016/j.aqpro.2015.02.126

Dooge, J. C. 1972. "Mathematical Models of Hydrologic Systems." Proceedings of the International Symposium on Modelling Techniques in Water Resources Systems, Ottawa, Canada 1:171-89.

Dwarakish, G. S. and B. P. Ganasri. 2015. "Impact of Land Use Change on Hydrological Systems: A Review of Current Modeling Approaches." Cogent Geoscience 1:1. https://doi.org/10.1080/23312041.2015.1115691
EAWAG (Eigenössische Anstalt für Wasserversorgung, Abwasserreinigung und Gewässerschutz). 2016. SWAT CUP software. Dübendorf: EAWAG. http://www.eawag.ch/de/abteilung/siam/software

Elliott, A. H. and S. A. Trowsdale. 2007. "A Review of Models for Low Impact Urban Stormwater Drainage." Environmental Modelling and Software 22 (3): 394-405.

El-Sharif, A. 1998. A Study of the Flooding Problem in Truro, NS. Halifax, NS: Dalhousie University. MEng Thesis.

Gosling, S. N., R. G. Taylor, N. W. Arnell and M. C. Todd. 2011. “A Comparative Analysis of Projected Impacts of Climate Change on River Runoff from Global and Catchment-Scale Hydrological Models." Hydrology and Earth System Sciences 15:279-94.

Haris, H., M. F. Chow, F. Usman, L. M. Sidek, Z. A. Roseli and M. D. Norlida. 2016. “Urban Stormwater Management Model and Tools for Designing Stormwater Management of Green Infrastructure Practices." In International Conference on Advances in Renewable Energy and Technologies (ICARET 2016), IOP Conference Series. Earth and Environmental Science 32 (2016): 012022. https://doi.org/10.1088/1755-1315/32/1/012022

Huber, W. and R. Dickinson. 1988. Stormwater Management Model, Version 4, Part A: User's Manual. Athens, GA: U.S. Environmental Protection Agency, Office of Research and Development. EPA/600/3-88/001a.

Jacomino, V. M. F. and D. E. Fields. 1997. "A Critical Approach to the Calibration of a Watershed Model." JAWRA Journal of the American Water Resources Association 33:143-54.

Jajarmizadeh, M., S. Harun and M. Salarpour. 2012. “A Review of Theoretical Consideration and Types of Models in Hydrology." Journal of Environmental Science and Technology 5 (5): 249-61.

Jang, S., M. Cho, J. Yoon, Y. Yoon, S. Kim, G. Kim, L. Kim and H. Aksoy. 2007. “Using SWMM as a Tool for Hydrologic Assessment." Desalination 212:344-56. https://doi.org/10.1016/j.desal.2007.05.005

Judi, D., A. J. Kalyanapu, T. McPherson and S. Burian. 2009. "Integration of SWMM into a Dam Break, Hurricane, and Extreme Flood Modeling and Damage Assessment Frame-work." Journal of Water Management Modeling 17: R235-13. doi: 10.14796/JWMM.R235-13.

Jun, S, J. H. Park, W. Lee, C. Park, S. Lee, K. Lee and G. C. Jeong. 2010. “The Changes in Potential Usable Water Resources by Increasing the Amount of Groundwater Use: The Case of Gapcheon Watershed in Korea." Geosciences Journal 14 (1): 33-9.

Kim, N. W., Y. S. Won, J. Lee and J. Jeong. 2011. "Hydrological Impacts of Urban Imperviousness in White Rock Creek Watershed." Transactions of the ASABE 54 (5): 1759-71.

Kuhn, C. 2014. Modeling Rainfall-Runoff Using SWAT in a Small Urban Wetland. FES 724 Watershed Cycles and Processes, 
Spring 2014. New Haven, CT: Yale University School of Forestry and Environmental Studies.

https://hixon.yale.edu/sites/default/files/files/report/kuhn_ finalreport_fes724.pdf

Lin, Z., D. E. Radcliffe, L. M. Risse, J. J. Romeis and C. R. Jackson. 2009. "Modeling Phosphorus in the Lake Allatoona Watershed using SWAT: II. Effect of Land Use Change." Journal of Environmental Quality 38 (1): 121-9.

Majors, K. and A. Acharya 2015. “Utilization of GIS Tools for Assessing Land Use/Cover Change for the Flint River Watershed." In Proceedings of the Alabama Water Resources Conference, Sep 9-11, 2015, Perdido Beach Resort, Orange Beach, Alabama. Mobile, AL: Auburn University. www.aes.auburn.edu/water

Morris, C. D. and J. P. Asunskis. 2002. “Modification of Detention Basin Outlet Structures Using Calibrated SWMM Model." Journal of Water Management Modeling 10: R208-16. doi: 10.14796/JWMM.R208-16.

Neitsch, S. L., J. G. Arnold, J. R. Kiniry, R. Srinivasan and J. R. Williams. 2002. Soil and Water Assessment Tool (SWAT) User's Manual (Version 2000). College Station, TX: Texas Water Resources Institute. https://swat.tamu.edu/media/1294/swatuserman.pdf

Neitsch, S.L., J. G. Arnold, J. R. Kiniry and J. R. Williams. 2009. Soil and Water Assessment Tool Theoretical Documentation, Version 2009. Temple, TX: Agricultural Research Service and Texas A \& M University. http://swat.tamu.edu/media/1292/swat2005theory.pdf

Perrelli, M. and K. Irvine. 2013. “Planning Level Modeling of E. Coli Levels in a Suburban Watershed Using PCSWMM." Journal of Water Management Modeling 21: R246-23. doi: 10.14796/JWMM.R246-23.

Pisinaras, V., C. Petalas, G. D. Gikas and A. Tsihrintzis. 2010. “Hydrological and Water Quality Modeling in a Medium-Sized Basin Using the Soil and Water Assessment Tool (SWAT)." Desalination 250 (1): 274-86.

Plate, E. J. 2009. “Classification of Hydrological Models for Flood Management." Hydrology and Earth System Sciences 13 :1939-51.

Rivard, G. 2010. “Small Storm Hydrology and BMP Modeling with SWMM5." Journal of Water Management Modeling 18: R236-10. doi: 10.14796/JWMM.R236-10.

Rossman, L. A. 2010. Storm Water Management Model User's Manual. Cincinnati OH: U.S. Environmental Protection Agency.

Santhi, C., R. Srinivasan, J. G. Arnold and J. R. Williams. 2006. “A Modeling Approach to Evaluate the Impacts of Water Quality Management Plans Implemented in a Watershed in Texas." Environmental Modeling and Software 21:1141-57.

Smith, D., J. Li and D. Banting. 2005. "A PCSWMM/GIS-Based Water Balance Model for the Reesor Creek Watershed." Atmospheric Research 77:388-406.
TDEC (Tennessee Department of Environment and Conservation). 2016. Wheeler Lake Watershed (06030002) of the Tennessee River Basin. Nashville, TN: Tennessee Department of Environment and Conservation. http://www.tennessee.gov/environment/article/ wr-ws-wheeler-lake-watershed\#sthash.4Q6LbYHu.dpuf

Tillinghast, E. D., W. F. Hunt and G. D. Jennings. 2011. "Stormwater Control Measure (SCM) Design Standards to Limit Stream Erosion for Piedmont North Carolina." Journal of Hydrology 411:185-96.

Tiveron, T., S. G. Kashi and D. Joksimovic. 2018. "A USEPA SWMM Integrated Tool for Determining the Suspended Solids Reduction Performance of Bioretention Cells." Journal of Water Management Modeling 26: C443. doi: 10.14796/JWMM.C443.

Tsihrintzis, V. A. and R. Hamid. 1998. "Runoff Quality Prediction from Small Urban Catchments Using SWMM." Hydrological Processes 12 (2): 311-29.

USDCM (Urban Drainage and Flood Control District). 2016. Urban Storm Drainage Criteria Manual: Volume 1-Management, Hydrology, and Hydraulics. Denver CO: Urban Drainage and Flood Control District.

https://udfcd.org/volume-one

USEPA (U.S. Environmental Protection Agency). 2015. BASINS 4.1 (Better Assessment Science Integrating point \& Non-point Sources) Modeling Framework. Research Triangle Park, NC: U.S. Environmental Protection Agency, National Exposure Research Laboratory. https://www.epa.gov/exposure-assessment-models/basins.

Van Liew, M. W., T. L. Veith, D. D. Bosch and J. G. Arnold. 2007. "Suitability of SWAT for the Conservation Effects Assessment Project: Comparison of USDA Agricultural Research Service Watersheds." Journal of Hydrologic Engineering 12 (2): 173-89.

Wu, J. Y., J. R. Thompson, R. K. Kolka, K. J. Franz and T. W. Stewart. 2013. “Using the Storm Water Management Model to Predict Urban Headwater Stream Hydrological Response to Climate and Land Cover Change." Hydrology and Earth System Sciences 17:4743-58.

Xu, C-Y. 1999. "Climate Change and Hydrological Models." Water Resources Management 13:369-82.

Xu, C-Y. 2002. Textbook of Hydrologic Models. Uppsala: Uppsala University, Department of Earth Sciences Hydrology.

Zhang, S. and Y. Guo. 2015. "SWMM Simulation of the Storm Water Volume Control Performance of Permeable Pavement Systems." Journal of Hydrologic Engineering 20 (8): 431-8.

Zhang X-S., F.-H. Hao, H.-G. Cheng and D.-F. Li. 2003. "Application of SWAT Model in the Upstream Watershed of the Luohe River." Chinese Geographic Science 13 (4): 334-9.

Zoppou, C. 2001. "Review of Urban Storm Water Models." Environmental Modeling and Software 16 (3): 195-231. 